\title{
Editorial \\ The evolving role of oestrogen receptor $\beta$ in clinical breast cancer
} Valerie Speirs

\author{
Pathology \& Tumour Biology, Leeds Institute of Molecular Medicine, St James's University Hospital, Leeds LS9 7TF, UK
}

Corresponding author: Valerie Speirs, v.speirs@leeds.ac.uk

Published: 19 September 2008

Breast Cancer Research 2008, 10:111 (doi:10.1186/bcr2140)

This article is online at http://breast-cancer-research.com/content/10/5/111

(c) 2008 BioMed Central Ltd

See related research article by Novelli et al., http://breast-cancer-research.com/content/10/5/R74

\begin{abstract}
Controversy surrounds the potential clinical importance of oestrogen receptor $(E R) \beta$ in breast cancer, and three recent papers have sought to resolve this. In the present issue of Breast Cancer Research Novelli and colleagues explored the significance of ER $\beta 1$ expression in 936 breast cancer patients, and they showed diverse relationships according to lymph node status. A second paper examined 442 breast cancers in which ER $\beta 1$ was an independent predictor of recurrence, disease-free survival and overall survival. Finally a third paper showed that ER $\beta 2$ was a powerful prognostic indicator in 757 breast cancers but this was dependent on cellular location, with nuclear ER 32 expression predicting good survival whilst cytoplasmic expression predicted worse outcome. These papers point to a clinical role for ER $\beta$ in breast cancer and shall be discussed.
\end{abstract}

Oestrogen receptor (ER) $\alpha$ remains the most important biomarker in breast cancer as it indicates the likelihood of patients to benefit from endocrine therapy. The discovery of ER $\beta$ over a decade ago was initially greeted with interest by the breast cancer community. Its presence indicated that ER signalling was no longer restricted to $E R \alpha$, with a real possibility of using ER $\beta$ as an additional prognostic or predictive marker in breast cancer, complementing ER $\alpha$. A number of studies were subsequently published, examining ER $\beta$ mRNA, protein or a combination of both - but many of these studies suffered from small sample numbers, use of poorly validated primary antibodies and failure to consider the potential importance of known ER $\beta$ isoforms. This led to conflicting results, holding back anticipated progress. As a result, a great deal of scepticism began to surround the potential importance of ER $\beta$ in breast cancer.

ER $\beta$ has recently emerged from the shadows with the concurrent publication of three papers [1-3]. These articles stand out from previous studies because they examined large numbers of breast cancers using well validated, readily available antibodies.
In the present journal, Novelli and colleagues conducted a prospective immunohistochemical study of ER $\beta 1$ in 936 breast cancers [1]. Rather than relying solely on conventional statistics to define ER $\beta$ association with clinicopathological factors, the authors used two additional statistical approaches: multiple correspondence analysis, and classification and regression tree analysis. The former approach analyses patterns of relationships of several categorical dependent variables, while the latter is a tree-building technique developed to reveal complex interactions between predictors that may be difficult to find using traditional multivariate techniques. Multiple correspondence analysis showed ER 11 positivity was associated with more aggressive breast cancer phenotypes, namely HER2-positive tumours and triple negative/basal breast cancers that do not express $E R \alpha$, progesterone receptor or HER2 - a relationship that has been observed by others $[3,4]$ (V. Speirs, unpublished observation).

In another recent study, Honma and colleagues showed ER $\beta 1$ was an independent predictor of recurrence, diseasefree survival and overall survival in 442 cases [3]. Although of mixed ER status, this cohort all received tamoxifen monotherapy with $E R \alpha^{-} E R \beta 1^{+}$phenotype tumours having survival advantage [3]. This observation suggests that the presence of any ER subtype, provided it is capable of binding ligand, can modulate an endocrine response.

The axillary lymph node status is an important prognostic factor in invasive breast cancer. Accordingly, Novelli and colleagues stratified their cohort into positive and negative lymph node status and examined the influence of ER $\beta 1$ expression on outcome in each cohort [1]. Using the classification and regression tree approach and validation by conventional statistics, ER $\beta 1$ expression predicted a high risk of relapse in the lymph node-positive group. At first glance these data might seem counterintuitive, given the general consensus that ER $\beta 1$ is a good prognostic factor in breast

$E R=$ oestrogen receptor 
cancer $[3,5,6]$. The study of Novelli and colleagues differs from most others, however, in that these patients were treated with adjuvant chemotherapy, whereas others have primarily studied patients receiving endocrine therapy. In lymph node-negative cases, by contrast, ER $\beta 1$ predicted a favourable response to endocrine therapy. These data are important; although positive node status predicted worse prognosis, some $30 \%$ of node-negative patients go on to experience relapse - an identification, therefore, of the need for potential prognostic factors in lymph node-negative cases. ER $\beta 1$ may fulfil a role in this regard.

Finally, it is important to highlight the role of cytoplasmic ER $\beta$ in dictating breast cancer outcome, something that has been consistently noted in many studies [2,3,7-9]. Shaaban and colleagues incorporated this into their immunohistochemical evaluation of ER $\beta 1, E R \beta 2$ and ER $\beta 5$ in 757 breast tumours [2]. In contrast to Novelli and colleagues [1] and Honma and colleagues [3], $E R \beta_{2}$ was the most significant $E R \beta$ isoform in terms of breast cancer outcome, as it was predictive of disease-free survival, overall survival and response to hormone therapy. This group also formally examined the presence of cytoplasmic ER $\beta$ immunoreactivity. Intriguingly, the cellular location of ER $\beta 2$ determined outcome - with nuclear ER $\beta 2$ predicting good clinical response, while cytoplasmic ER $\beta 2$ expression predicted significantly worse overall survival. This was confirmed in 322 independent cases.

These studies put ER $\beta$ firmly back into the spotlight as a potentially important player in ER signalling and hormonedependent cancer, with not only specific ER $\beta$ isoforms determining outcome but also their precise cellular location. ER $\beta$ isoforms should now be considered in translational arms of breast cancer trials where their potential clinical role can be addressed more rigorously.

\section{Competing interests}

The author declares that they have no competing interests.

\section{References}

1. Novelli F, Milella M, Melucci E, Di Benedetto A, Sperduti I, Perrone-Donnorso R, Perrachio L, Venturo I, Nistico C, Fabi A, Buglioni S, Giorgio Natali P, Mottolese M: A divergent role for estrogen receptor beta in node-positive and node-negative breast cancer classified according to molecular subtypes: an observational prospective study. Breast Cancer Res 2008, 10: R74.

2. Shaaban AM, Green AR, Karthik S, Alizadeh Y, Hughes TA, Harkins L, Ellis IO, Robertson JF, Paish EC, Saunders PT, Groome NP, Speirs V: Nuclear and cytoplasmic expression of ER $\beta 1$, ERB2, and ERß5 identifies distinct prognostic outcome for breast cancer patients. Clin Cancer Res 2008, 14:5228-5235.

3. Honma N, Horii R, Iwase T, Saji S, Younes M, Takubo K, Matsuura $M$, Ito $Y$, Akiyama F, Sakamoto G: Clinical importance of estrogen receptor- $\beta$ evaluation in breast cancer patients treated with adjuvant tamoxifen therapy. J Clin Oncol 2008, 26:37273734.

4. Skliris GP, Leygue E, Curtis-Snell L, Watson PH, Murphy LC: Expression of oestrogen receptor- $\beta$ in oestrogen receptor- $\alpha$ negative human breast tumours. Br J Cancer 2006, 95:616626.

5. Nakopoulou L, Lazaris AC, Panayotopoulou EG, Giannopoulou I,
Givalos N, Markaki S, Keramopoulos A: The favourable prognostic value of oestrogen receptor $\beta$ immunohistochemical expression in breast cancer. J Clin Pathol 2004, 57:523-528.

6. Saji S, Hirose M, Toi M: Clinical significance of estrogen receptor $\beta$ in breast cancer. Cancer Chemother Pharmacol 2005, 56 (Suppl 1):21-26.

7. Jensen EV, Cheng G, Palmieri C, Saji S, Mäkelä S, Van Noorden S, Wahlström T, Warner M, Coombes RC, Gustafsson JA: Estrogen receptors and proliferation markers in primary and recurrent breast cancer. Proc Natl Acad Sci U S A 2001, 98: 15197-15202.

8. Skliris GP, Parkes AT, Limer JL, Burdall SE, Carder PJ, Speirs V: Evaluation of seven oestrogen receptor $\beta$ antibodies for immunohistochemistry, western blotting, and flow cytometry in human breast tissue. J Patho/ 2002, 197:155-162.

9. Shaaban AM, O'Neill PA, Davies MP, Sibson R, West CR, Smith $\mathrm{PH}$, Foster CS: Declining estrogen receptor- $\beta$ expression defines malignant progression of human breast neoplasia. Am J Surg Pathol 2003, 27:1502-1512. 